\title{
Sclerotherapy of Benign Oral Vascular Lesions with Non-Diluted Ethanolamine Oleate
}

\author{
Escleroterapia de Lesiones Vasculares Orales Benignas \\ con Oleato de Etanolamina no Diluido
}

Portella, P. D. ${ }^{1}$; Bedra, L. B. ${ }^{2}$; Perdoncini, N. N. ${ }^{1}$; Amenábar, J. M. ${ }^{3}$ \& Torres-Pereira, C. C. ${ }^{3}$

PORTELLA, P. D.; BEDRA, L. B.; PERDONCINI, N. N.; AMENÁBAR, J. M. \& TORRES-PEREIRA, C. C. Sclerotherapy of benign oral vascular lesions with non-diluted ethanolamine oleate. Int. J. Odontostomat., 14(3):373-379, 2020.

\begin{abstract}
Benign oral vascular lesions are anomalies characterized by the blood vessels proliferation or malformation and the treatment with the sclerosing agent ethanolamine oleate acts irrigating the vessel producing a sterile inflammatory response. The objective of this study was to report and discuss the results from treatment of benign oral vascular lesions with non-diluted ethanolamine oleate through the analysis of clinical records. The sample was composed by the selection of twenty-six patients (12 male and 14 female), with oral vascular malformations. All lesions were treated with intralesional injections of undiluted ethanolamine oleate. These patients attended in Oral Medicine outpatient clinic of the Federal University of Paraná between the years of 2011 to 2015 . The average age was 60.65 years, with a higher prevalence for women. The majority of the individuals had one lesion and its location was mostly in the lower lip. The main complaint was about a physical discomfort. The lesions had the average size of $6.52 \mathrm{~mm}$ and received a median number of 2.32 applications. Only one patient reported feeling pain in the postoperative week. In most cases the resolution of the lesion was considered partial. Follow-up was obtained up to one month after the end of treatment. The sclerotherapy with undiluted ethanolamine oleate shows acceptable results in the treatment of small benign oral vascular lesions with a few minor side effects.
\end{abstract}

KEY WORDS: sclerotherapy, hemangioma, oral lesions.

\section{INTRODUCTION}

Benign oral vascular lesions (BOVL) are anomalies characterized by blood vessel proliferation or malformation (Costa Filho et al., 2011). The clinical term used to designate the oral lesions normal cycle of endothelial cells are oral vascular malformation while lesions with endothelial proliferation are called hemangiomas (Costa Filho et al.). According to the literature, oral vascular malformations may be caused by local trauma, infection, metabolic alterations or truly neoplasia (Costa et al., 2011; Gheno et al., 2015). The lesion clinical appearance and its physical examination are usually enough for the BOVL diagnosis (Pedron et al., 2008). However, in some cases, these lesions may present non-pathognomonic clinical features that require a diascopy or punction to obtain the differential diagnosis (Cruz et al., 2011).
The prevalence of BOVL in Brazil is $6.4 \%$ (Corrêa et al., 2007) and the highest incidence for hemangiomas or vascular malformations occurs just after birth or in early childhood, while for varicose veins the incidence is higher among seniors. Minor oral benign vascular lesions are common in the head and neck region (Corrêa et al.). In the mouth, BOVL can be found mainly on the lips, tongue, buccal mucosa, and palate, with a predilection for women (Costa Filho et al.). In some cases, the lesions are asymptomatic, tend to be self-limiting and may resolve spontaneously without any therapeutic intervention (Sarmiento et al., 2008). However, in some occasion BOVL may have progressive growth, facilitating local traumatic injuries causing pain, ulceration, secondary infections and spontaneous bleeding (Johann et al., 2005). The most

\footnotetext{
${ }^{1}$ Bachelor of Dentistry, Postgraduate of Master Dentistry at Federal University of Paraná, Av. Prefeito Lothário Meissner, 632, Curitiba 81530 380, Brazil.

2 Bachelor of Dentistry, University Federal of Paraná, Av. Prefeito Lothário Meissner, 632, Curitiba 81530 380, Brazil.

${ }^{3}$ Phd of Stomatology Clinical, Teacher of Stomatology at Federal University of Paraná, Av. Prefeito Lothário Meissner, 632, Curitiba 81530 380, Brazil.
} 
common clinical features for a BOVL are the resilient papular or nodular red lesion, mostly with an irregular or lobulated surface (Cruz et al.).

The conventional surgical excision, electrosurgery, laser ablation, cryotherapy and chemical sclerotherapy are the most common therapeutic options for the treatment of minor BOVL (Jaeger et al., 2013). The sclerosing agent ethanolamine oleate acts irritating the vessel endothelial inner layer producing a sterile inflammatory response. This results in the fibrosis of the vessel wall and the possible vein obliteration. It is indicated for treatment of varicose veins or small varicosities, as long as there are no vascular diseases, in which case the therapy not only is ineffective, but can also result in phlebitis with extensive thrombus formation (Zanettini et al., 2005). This therapy is also contraindicated in patients with uncontrolled diabetes or ulcerated and secondary infected injuries (Zanettini et al.; Gómez Oliveira et al., 2008). The clinical characteristics and treatment of BOVL depend on the vascular congestion level and location (Corrêa et al.). Thus, the objective of this study was to report and discuss the results from treatment of benign oral vascular lesions with non-diluted ethanolamine oleate through the analysis of clinical records.

\section{MATERIAL AND METHOD}

The sample was composed by the selection of all patient records with minor BOVL treated with undiluted ethanolamine oleate. A total of twenty-six patients (11 male and 15 female) were selected, who exhibited 36 examples of oral vascular anomalies that were treated with intralesional injections of the sclerosing agent. These patients were seen in the Oral Medicine outpatient clinic of the Federal University of Paraná, between the years 2011 to 2015.

The treatment consisted of an intralesional application of $5 \%$ ethanolamine oleate with an insulin syringe with a $0.3 \times 13 \mathrm{~mm}$ needle and $0.05 \mathrm{~mL}$ to 0.5 $\mathrm{mL}$ of the drug was delivered directly to the affected tissue per application. No dilution was used in any case.

The clinical charts were reviewed and the individuals' clinical information such as age, sex, skin color, main complaint, systemic diseases, smoking habits, use of dental prosthesis and follow up were obtained. The lesion characteristics were recorded regarding size, location, ethanolamine oleate dose injected, number of applications, symptoms and resolution.

Two researchers (LBB and PDP) were responsible to independently review, re-check and compare any differences in the information gathered from the clinical charts. Any conflicting information was resolved by consensus and by a third part independent researcher (CCTP).

The data were registered in the software Statistical Package for Social Sciences for descriptive statistics.

The Ethics Research Committee of the Health Sciences Center of the Federal University of Paraná (UFPR), Brazil, approved the present retrospective study (protocol n`810.145.09.10).

\section{RESULTS}

From the 26 patients treated, the mean age was 60.65 , ranging from 9 to 78 years. Regarding skin color there was a great majority of white $(n=24)$, one black and one individual with no data registered. Among the patients with minor BOVL, 15 were female $(57.69 \%)$ and 11 male $(42.31 \%)$.

The most recorded chief complaint was physical discomfort, (52.78\%), followed by esthetic concern (11.12\%) (Table I). The most common lesion site was the lower lip (38.89\%), followed by the upper lip, buccal mucosa and labial commissure (Table II). Nineteen patients showed one single BOVL $(73.08 \%)$ and five presented two lesions each $(19.23 \%)$. Only two patients showed more than two lesions $(7.9 \%)$.

The average initial size was $6.52 \mathrm{~mm}$, ranging from $1 \mathrm{~mm}$ to $20 \mathrm{~mm}$ before the treatment. In all the 36 studied lesions 79 applications were made with an average of 2.32 applications per lesion. The highest number of applications that a lesion demanded was 8 , and the lesion with fewer applications received only one.

As the amount of injected sclerosing agent, in 23 injections this data was not documented in the patient's record. Three patients reported a burning sensation at the site during administration. The injection was performed under topical anesthesia in all cases 
Table I. Clinical Information collected from patients with benign oral vascular lesions treated in the Oral Medicine Clinic from the Federal University of Paraná, 2011-2015.

\begin{tabular}{|c|c|c|c|c|c|}
\hline Patient & Age & Sex & Skin Color & Main Complaint & Other Lesions \\
\hline $\mathrm{P} 1$ & 77 & Male & White & Physical Discomfort & LP \\
\hline P2 & 78 & Female & White & Physical Discomfort & $\mathrm{IFH}, \mathrm{EC}$ \\
\hline P3 & 72 & Male & White & Physical Discomfort & NONE \\
\hline P4 & 67 & Female & White & Not Specified & NONE \\
\hline P5 & 57 & Female & White & Physical Discomfort & $S$ \\
\hline P6 & 30 & Male & White & Physical Discomfort & NONE \\
\hline P7 & 68 & Female & White & Physical Discomfort & NONE \\
\hline P8 & 71 & Male & White & Not Specified & IFH \\
\hline P9 & 54 & Female & White & Physical Discomfort & NONE \\
\hline P10 & 70 & Female & White & Physical Discomfort & DS \\
\hline P11 & 65 & Female & White & Physical Discomfort & IPH, HFI \\
\hline P12 & 65 & Female & White & Physical Discomfort & IFH, SM,AT \\
\hline P13 & 57 & Female & White & Physical Discomfort & NONE \\
\hline P14 & 57 & Male & White & Physical Discomfort & NONE \\
\hline P15 & 53 & Male & White & Physical Discomfort & NONE \\
\hline P16 & 35 & Female & White & Esthetic & NONE \\
\hline P17 & 68 & Female & White & Physical Discomfort & NONE \\
\hline P18 & 68 & Male & Black & Esthetic & NONE \\
\hline P19 & 9 & Female & White & Physical Discomfort & NONE \\
\hline P20 & 55 & Female & White & Physical Discomfort & IFH \\
\hline P21 & 59 & Male & $\mathrm{NI}$ & Physical Discomfort & NONE \\
\hline P22 & 54 & Female & White & Physical Discomfort & NONE \\
\hline P23 & 77 & Female & White & Esthetic & NONE \\
\hline P24 & 71 & Male & White & Physical Discomfort & M \\
\hline P25 & 67 & Male & White & Esthetic & $\mathrm{P}$ \\
\hline P26 & 73 & Male & White & Physical Discomfort & NONE \\
\hline
\end{tabular}

$\mathrm{AT}=$ Amalgam Tattoo; $\mathrm{DS}=$ Denture Stomatitis; $\mathrm{EC}=$ Erythematous Candidiasis; $\mathrm{IFH}=$ Inflammatory Fibrous Hyperplasia; IPH = Inflammatory Papillary Hyperplasia; LP= Lichen Planus; $\mathrm{M}=$ Melanosis; $\mathrm{NI}=$ No information; $\mathrm{P}=$ Papilloma; $\mathrm{S}=$ Sialolithiasis. .

Table II. Lesion site, frequency and percentage of benign oral vascular malformations. Oral Medicine Clinic from the Federal University of Paraná, 2011-2015.

\begin{tabular}{lcc}
\hline \multicolumn{1}{c}{ Lesion Site } & Frequency $\left(\mathrm{N}^{\circ}\right)$ & Percentage $(\%)$ \\
\hline Lower Lip & 14 & 38.89 \\
Upper Lip & 6 & 16.66 \\
Buccal Mucosa & 4 & 11.11 \\
Labial Commissure & 4 & 11.11 \\
Tongue Border & 3 & 8.33 \\
Vestibule & 2 & 5.55 \\
Tongue Dorsum & 1 & 2.78 \\
Floor Of Mouth & 1 & 2.78 \\
Alveolar Mucosa & 1 & 2.78 \\
\hline
\end{tabular}

and non-opioid analgesics and compress ice were prescribed. At the minimum one week recheck after application the main signal observed was the lesion shrinkage with local fibrosis, reported in 8 cases $(22.22$ $\%)$ record. In the 13 cases in which the record was properly filled the average amount applied was $0.25 \mathrm{~mL}$. The higher volume used in a single injection was 0.5 $\mathrm{mL}$ and $0.05 \mathrm{~mL}$ was the smallest volume. In $63.88 \%$
$(n=X)$ of the lesions this data was not reported. There were other minor side effects observed after applications such as 1 case of pain, 1 of ulceration, 1 of edema and 1 of numbness sensation, totalizing $11.11 \%$.

After the last application of the sclerosing agent was the total or partial resolution of the lesions was evaluated (Figs. 1 and 2). In most cases the resolution of the lesion was partial $(n=19,52.78 \%)$, as shown in Table III. Again, a large number of records on lesion size at follow-up were unavailable from the charts $(n=10,27.78 \%)$. Thirteen individuals did not discontinue treatment. No information was available on the motivation for the treatment interruption and no cases were submitted to a complementation with surgical intervention.

The patients' follow up is shown in Figure 3. From the 26 patients, this data could only be retrieved from $15(57.69 \%)$. Seven patients $(26.92 \%)$ were followed up to one month after the end of treatment. 
A
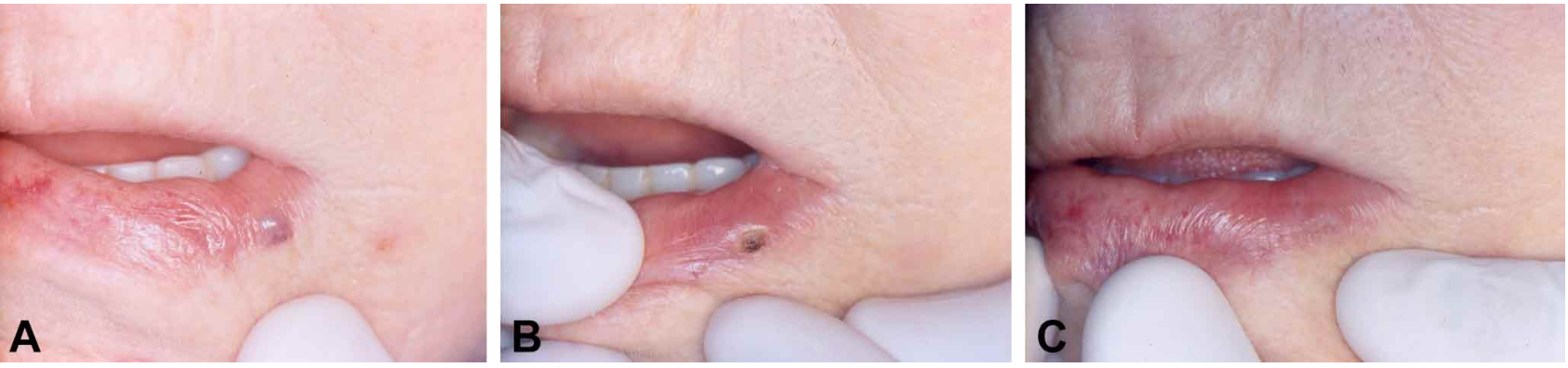

Fig. 1. A: Lesion appearance prior to the first ethanolamine oleate application. B: Lesion aspect after the first injection. C: the complete resolution after the sclerotherapy.

Table III. Benign oral vascular lesions treated with 5\% undiluted ethanolamine oleate and its resolutions. Oral Medicine Clinic from the Federal University of Paraná, 2011-2015.

\begin{tabular}{|c|c|c|c|c|c|c|}
\hline $\begin{array}{l}\text { Patient } \\
\text { (P) } n=26\end{array}$ & $\begin{array}{l}\text { Lesion }(L) \\
\quad n=36\end{array}$ & Size $(\mathrm{mm})$ & $\begin{array}{l}\text { Number of } \\
\text { applications }\end{array}$ & $\begin{array}{l}\text { Average Amount } \\
\text { Injected (mL) }\end{array}$ & Resoluton & $\begin{array}{c}\text { Treatment } \\
\text { discontinuation }\end{array}$ \\
\hline P1 & L1 & 10 & 2 & $\mathrm{NI}$ & Total & NO \\
\hline $\mathrm{P} 2$ & L1 & 4 & 2 & $\mathrm{NI}$ & Partial & YES \\
\hline \multirow[b]{2}{*}{ P3 } & L1 & 13 & 4 & $\mathrm{NI}$ & Partial & YES \\
\hline & L2 & 3 & 2 & $\mathrm{NI}$ & Partial & YES \\
\hline P4 & L1 & 20 & 1 & $\mathrm{NI}$ & NI & YES \\
\hline \multirow{2}{*}{ P5 } & L1 & $\mathrm{NI}$ & 1 & 0.2 & Partial & YES \\
\hline & L2 & $\mathrm{NI}$ & 1 & 0.05 & $\mathrm{NI}$ & YES \\
\hline P6 & L1 & 5 & 1 & $\mathrm{NI}$ & Partial & YES \\
\hline \multirow[t]{2}{*}{ P7 } & L1 & $\mathrm{NI}$ & 4 & $\mathrm{NI}$ & Partial & NO \\
\hline & L1 & 5 & 1 & $\mathrm{NI}$ & Total & NO \\
\hline \multirow{3}{*}{ P8 } & L2 & 3 & 1 & $\mathrm{NI}$ & Partial & NO \\
\hline & L3 & 1 & 1 & NI & Partial & NO \\
\hline & L4 & 2 & 1 & $\mathrm{NI}$ & Partial & NO \\
\hline \multirow[b]{2}{*}{ P9 } & L1 & 8 & 2 & 0.8 & Partial & NO \\
\hline & L2 & $\mathrm{NI}$ & $\mathrm{NI}$ & $\mathrm{NI}$ & $\mathrm{NI}$ & NO \\
\hline \multirow{2}{*}{ P10 } & L1 & 4 & 2 & $\mathrm{NI}$ & Partial & YES \\
\hline & L2 & $\mathrm{NI}$ & 1 & $\mathrm{NI}$ & $\mathrm{NI}$ & YES \\
\hline P11 & L1 & 5 & 2 & $\mathrm{NI}$ & Partial & NO \\
\hline P12 & L1 & 3 & 5 & 0.35 & Total & NO \\
\hline P13 & L1 & 5 & 1 & 0.2 & NI & YES \\
\hline P14 & L1 & 10 & 1 & $\mathrm{NI}$ & $\mathrm{NI}$ & YES \\
\hline P15 & L1 & $\mathrm{NI}$ & 5 & $\mathrm{NI}$ & Partial & $\mathrm{NI}$ \\
\hline P16 & L1 & 4 & 1 & 1.5 & Partial & NO \\
\hline \multirow{2}{*}{ P17 } & L1 & 6 & 8 & 0.2 & Partial & NO \\
\hline & L2 & 6 & 8 & $\mathrm{NI}$ & Partial & NO \\
\hline P18 & L1 & 10 & 1 & NI & NI & YES \\
\hline P19 & L1 & 5 & 2 & $\mathrm{NI}$ & Total & NO \\
\hline P20 & L1 & 10 & 1 & $\mathrm{NI}$ & Partial & NO \\
\hline P21 & L1 & 5 & 3 & $\mathrm{NI}$ & Total & $\mathrm{NI}$ \\
\hline $\mathrm{P} 22$ & L1 & $\mathrm{NI}$ & 1 & 0.2 & Partial & YES \\
\hline P23 & L1 & $\mathrm{NI}$ & 1 & 0.05 & NI & $\mathrm{NI}$ \\
\hline \multirow{2}{*}{ P24 } & L1 & 6 & 5 & 0.23 & Partial & NO \\
\hline & L2 & 6 & 3 & 0.25 & Total & NO \\
\hline P25 & L1 & 5 & 2 & 0.4 & Total & NO \\
\hline \multirow{2}{*}{ P26 } & L1 & 10 & 4 & $\mathrm{NI}$ & $\mathrm{NI}$ & NO \\
\hline & L2 & 10 & $\mathrm{NI}$ & NI & $\mathrm{NI}$ & NO \\
\hline
\end{tabular}

$\mathrm{NI}=$ No information. 


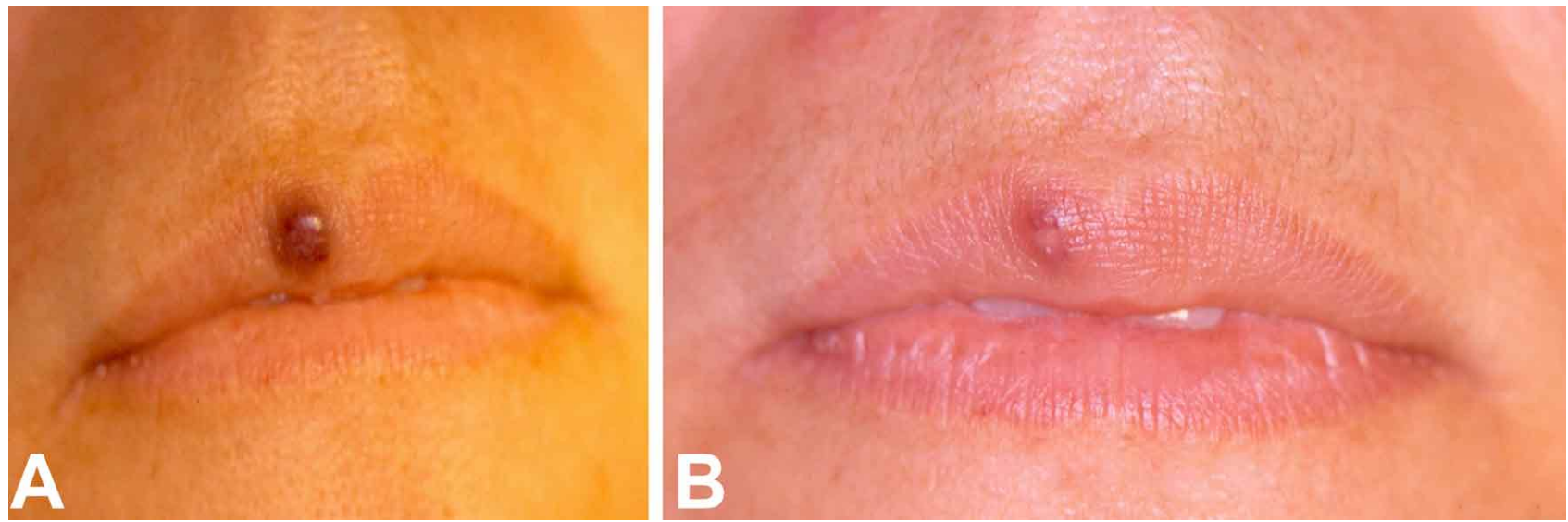

Fig. 2. A: BOVL in the upper lip region after any procedure was made. B: Partially solved case aspect from the upper lip BOVL.

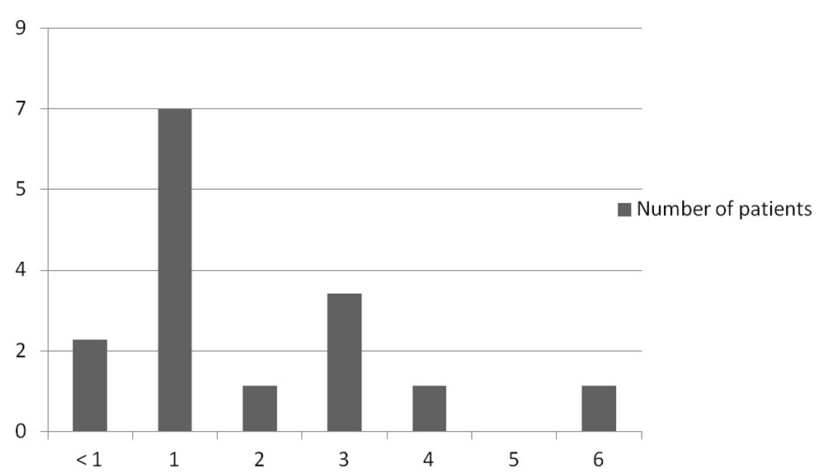

Fig. 3. The number of individuals treated with ethanolamine oleate and the follow up months after the last sclerosing agent application.

\section{DISCUSSION}

The minor BVOL's are characterized by an anomaly of the blood vessels with or without endothelium proliferation. They can be found as congenital diseases, or be a true neoplasm such as hemangiomas or yet, develop characteristically as part of aging in the case of varicose veins (Costa Filho et al.). BOVL's can cause ulceration, pain, bleeding, secondary infection and deformation of tissue (Johann et al.). In such cases options for treatment are also variable including electrosurgery, laser ablation, cryotherapy, chemical sclerotherapy or even cold blade surgical removal (Jaeger et al.). Asymptomatic cases are normally subjected exclusively to clinical follow up unless patients manifest an esthetic concern (Cardoso et al., 2010).

There is no gold standard treatment for symptomatic lesions. The vascular congestion level and lesion depth will usually guide therapy (Zanettini et al.).
All lesions evaluated in this study were small, which was an important factor in the choice of the therapeutic procedure. We chose to use ethanolamine oleate due to its low cost and also on behalf of the minor side effects described in the literature when compared with other sclerosis-inducing agents (Hyodoh et al., 2005).

Other papers describing the use of ethanolamine oleate to perform sclerotherapy of vascular lesions use dilution of the sclerosing agent prior to intralesional application (Johann et al.; Zanettini et al.; Sarmiento et al.). In all cases reported in this study, $5 \%$ ethanolamine oleate was applied in its original concentration, with a smaller volume and no negative results could be observed when compared to other modalities of treatment described for minor BVOL's (Zanettini et al.; Hoque \& Das, 2011; Jaeger et al.). In this research there were only 1 case of an ulcer and 3 cases of other minor effects $(11.11 \%)$.

The average number of applications per lesion was 2.32 , a slightly lower mean when compared to the 3.07 (Johann et al.) or the 2.41 (da Silva et al., 2014) found by other studies.

Of the 26 patients, only $50 \%(n=13)$ completed the treatment. These 13 patients had a total of 20 lesions. For those 20 lesions, $55 \%(n=11)$ had a partial resolution, $30 \%(n=6)$ reached full resolution and in $15 \%$ of the cases this information was not clear in the clinical records. It seems our cases performed poorer in comparison to other studies that described full remission in $92.94 \%$ (da Silva et al.) to $100 \%$ (Johann et al.) of the cases. We speculate that the present research has presented stricter criteria to consider full remission probably due to its retrospective design. It is also important to note, the high number of uncompleted treatments. 
The application of ethanolamine oleate was performed every week, as proposed in the study conducted by da Silva et al. However, other authors report intervals between applications ranging from weekly to every 6 weeks (Johann et al.; Sarmiento et al.; Eivazi et al., 2009; Costa et al.; Costa Filho et al.; Hoque \& Das; da Silva et al.).

No dilution was made prior to the applications, and the major amount injected was $0.5 \mathrm{~mL}$ of ethanolamine oleate. However, there are some other protocols that recommend diluting the ethanolamine oleate with distilled water in the proportion of $1 / 2$ and $1 / 4$, resulting in the concentrations of $2.5 \%$ and 1.25 $\%$ respectively (Zanettini et al.; Pedron et al.). The smaller concentrations allow a higher volume of the drug to be injected $(1 \mathrm{~mL})$ diminishing renal toxicity risk (Jaeger et al.). It has to be yet clarified if the use of diluted ethanolamine oleate improves the number of BVOL in complete remission at the end of treatment.

As other retrospective studies, there are some design limitations. There was a significant amount of missing information in clinical charts that could have helped to understand the lesion remission and its relation to ethanolamine application and dosage. Another relevant drawback was the short period of follow-up which do not allow for the conclusion of long term effects of ethanolamine oleate as a definitive therapeutic approach to minor BOVL's in the present sample. The present study showed that in most cases the follow up was one month. Other studies showed postoperative follow-up of 2 to 30 months and did not show recurrence during their larger study period of observation (Gomes et al., 2006; da Silva et al.).

The present study has some limitations that are inherent to its methodological design. Furthermore, the benign oral vascular lesions have a low prevalence, making it difficult to select the representative sample and compromising external validity. Thus, others studies with a longitudinal design and a probabilistic sample are needed to generalize this finding and establish a treatment protocol for these lesions.

In conclusion, the present results agree with previous published papers that recommend ethanolamine oleate as a safe and predictable option in small BVOL's. In addition, this study demonstrated that those with side effects were lower in the sample when sclerotherapy was performed at fewer clinic visits and at weekly intervals with lower volumes of $5 \%$ undiluted intralesional injection.
PORTELLA, P. D.; BEDRA, L. B.; PERDONCINI, N. N.; AMENÁBAR, J. M. \& TORRES-PEREIRA, C. C. Escleroterapia de lesiones vasculares orales benignas con oleato de etanolamina no diluido. Int. J. Odontostomat., 14(3): 373-379, 2020.

RESUMEN: Las lesiones vasculares orales benignas son anomalías caracterizadas por la proliferación o malformación de los vasos sanguíneos y el tratamiento con el agente esclerosante etanolamina oleato actúa irrigando el vaso produciendo una respuesta inflamatoria estéril. El objetivo de este estudio fue informar y discutir los resultados del tratamiento de lesiones vasculares orales benignas con oleato de etanolamina no diluido a través del análisis de historias clínicas. La muestra estuvo compuesta por la selección de veintiséis pacientes (12 hombres y 14 mujeres), con malformaciones vasculares orales. Todas las lesiones fueron tratadas con inyecciones intralesionales de oleato de etanolamina sin diluir. Estos pacientes acudieron a la clínica ambulatoria de Medicina Oral de la Universidad Federal de Paraná entre los años 2011 a 2015. La edad promedio fue de 60,65 años, con una mayor prevalencia para las mujeres. La mayoría de los individuos tenían una lesión y su ubicación era principalmente en el labio inferior. La queja principal era sobre una molestia física. Las lesiones tenían un tamaño promedio de 6,52 $\mathrm{mm}$ y recibieron una mediana de 2,32 aplicaciones. Solo un paciente informó haber sentido dolor en la semana postoperatoria. En la mayoría de los casos, la resolución de la lesión se consideró parcial. El seguimiento se obtuvo hasta un mes después del final del tratamiento. La escleroterapia con oleato de etanolamina sin diluir muestra resultados aceptables en el tratamiento de pequeñas lesiones vasculares orales benignas con algunos efectos secundarios menores.

PALABRAS CLAVE: escleroterapia, hemangioma, lesiones.

\section{REFERENCES}

Cardoso, C. L.; Fernandes, L. M. P. S. R.; Rocha, J. F.; Gonçales, E. S.; Ferreira Júnior, O. \& Taveira, L. A. S. Abordagem cirúrgica de hemangioma intraoral. Odontol. Clin. Cient., 9(2):177-80, 2010.

Corrêa, P. H.; Nunes, L. C.; Johann, A. C.; Aguiar, M. C.; Gomez, R. S. \& Mesquita, R. A. Prevalence of oral hemangioma, vascular malformation and varix in a Brazilian population. Braz. Oral Res., 21(1):40-5, 2007.

Costa Filho, J. Z.; dos Santos, C. A. I. S.; Costa, M. C.; Costa, P. J. C. \& Nobre, S. M. W. Oleato de etanolamina $5 \%$ como opção ao tratamento cirúrgico dos hemangiomas orais: relato de caso. Rev. Cir. Traumatol. Buco-Maxilo-Fac., 11(4):31-6, 2011.

Costa, J. R.; Torriani, M. A.; Hosni, E. S.; D'Avila, O. P. \& de Figueiredo, P. J. Sclerotherapy for vascular malformations in the oral and maxillofacial region: treatment and follow-up of 66 lesions. J. Oral Maxillofac. Surg., 69(6):e88-92, 2011.

Cruz, F. L. G.; de Carvalho, R. F.; de Carvalho, M. F.; Sales, L. A. R. \& Devito, K. L. Diagnóstico diferencial de hemangioma por meio da vitropressão. R. G. O. Rev. Gauch. Odontol., 59(1):125-9, 2011. 
da Silva, W. B.; Ribeiro, A. L.; de Menezes, S. A.; de Jesus Viana Pinheiro, J. \& de Melo Alves-Junior, S. Oral capillary hemangioma: a clinical protocol of diagnosis and treatment in adults. Oral Maxillofac. Surg., 18(4):431-7, 2014.

Eivazi, B.; Ardelean, M.; Bäumler, W.; Berlien, H. P.; Cremer, H.; Elluru, R.; Koltai, P.; Olofsson, J.; Richter, G.; Schick, B.; et al. Update on hemangiomas and vascular malformations of the head and neck. Eur. Arch. Otorhinolaryngol., 266(2):187-97, 2009.

Gheno, J. N.; Martins, M. A.; Munerato, M. C.; Hugo, F. N.; Sant'ana Filho, M.; Weissheimer, C.; Carrard, V. C. \& Martins, M. D. Oral mucosal lesions and their association with sociodemographic, behavioral, and health status factors. Braz. Oral Res., 29(1):1-6, 2015.

Gomes, C. C.; Gomez, R. S.; do Carmo, M. A.; Castro, W. H.; GalaGarcía, A. \& Mesquita, R. A. Mucosal varicosities: case report treated with monoethanolamine oleate. Med. Oral Patol. Oral Cir. Bucal, 11(1):E44-6, 2006.

Gómez Oliveira, G.; García-Rozado, A. \& Luaces Rey, R. Intraosseous mandibular hemangioma. A case report and review of the literature. Med. Oral Patol. Oral Cir. Bucal, 13(8):E496-8, 2008.

Hoque, S. \& Das, B. K. Treatment of venous malformations with ethanolamine oleate: a descriptive study of 83 cases. Pediatr. Surg. Int., 27(5):527-31, 2011.

Hyodoh, H.; Hori, M.; Akiba, H.; Tamakawa, M.; Hyodoh, K. \& Hareyama, M. Peripheral vascular malformations: imaging, treatment approaches, and therapeutic issues. Radiographics, 25 Suppl. 1:S159-71, 2005.

Jaeger, F.; López Alvarenga, R.; Fernandes Galizes, B.; Girardi, G. P.; López Alvarenga, G. \& Leal, R. M. Escleroterapia com oleato de etanolamina a $5 \%$ em hemangioma oral: relato de caso clínico. Rev. Port. Estomatol. Med. Dent. Cir. Maxilofac., 54(2):914, 2013.

Johann, A. C.; Aguiar, M. C.; do Carmo, M. A.; Gomez, R. S.; Castro, W. H. \& Mesquita, R. A. Sclerotherapy of benign oral vascular lesion with ethanolamine oleate: an open clinical trial with 30 lesions. Oral Surg. Oral Med. Oral Pathol. Oral Radiol. Endod., 100(5):579-84, 2005.

Pedron, I. G.; Carnaval, T. G.; Loureiro, C. C. S.; Utumi, E. R.; Magalhães, J. C. A. \& Adde, C. A. Opção terapêutica de hemangioma labial. Rev. Inst. Cienc. Saúde, 26(4):477-81, 2008.

Sarmiento, M. E.; Espinosa, I. V.; Quiñones, L. T. \& Arias, A. B. Tratamiento quirúrgico de los hemangiomas faciales en niños. Rev. Esp. Cir. Oral Maxilofac., 30(4):274-80, 2008.

Zanettini, I.; Zanettini, R. M. \& Gollo, G. Sclerotherapy as an alternative treatment for oral vascular pathologies. Clin. Pesq. Odontol., 2(2):119-26, 2005.
Corresponding author:

Paula Dresch Portella

Técnica em Gestão Empresarial - UTFPR

Cirurgiã-Dentista - UFPR

Mestre em Odontologia - UFPR

Doutoranda em Odontologia (área de concentração Odontopediatria) - UFPR

BRAZIL

Email: pauladresch@hotmail.com

Received: 25-11-2019

Accepted: 10-02-2020 